\title{
Protective effect of selenium against oxidative stress for biochemical and blood parameters in Ovariectomyzed and cadmium exposured female rats
}

\author{
Talib Hussen Ali $\quad \& \quad$ Ahmed Baker Ali \\ Department of Biology / College of Education \\ University of Mosul \\ \&

\section{Heyam Natheer Matti} \\ Department of Physiology / College of Veterinary \\ University of Mosul
}

Received

27 / 07 / 2010
Accepted

03 / 11 / 2010

\section{الخلاصـة}

يهدف البحث الحالي إلى إمكانية الثأثير الوقائي لكلوريد السيلينيوم المضاد للكرب

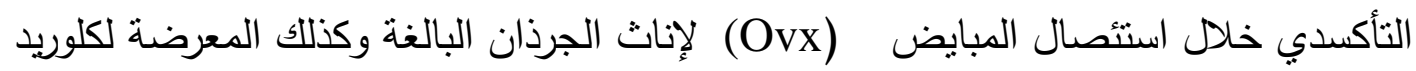

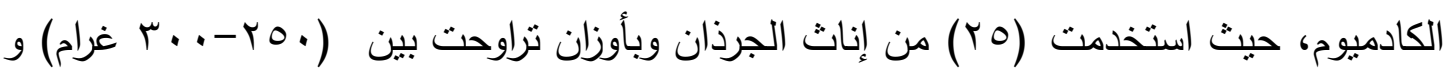

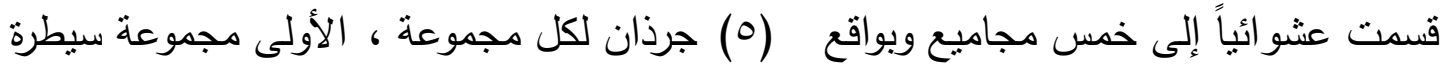

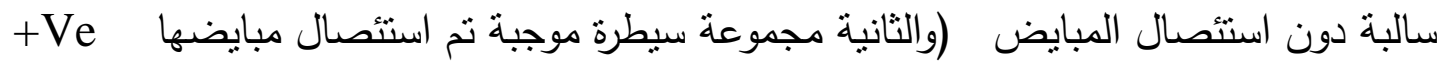

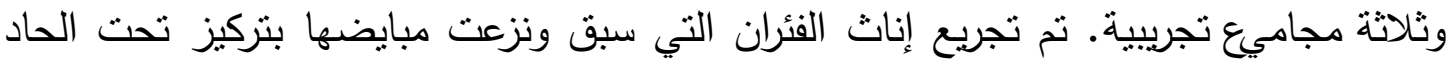

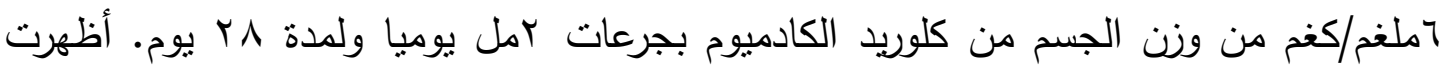

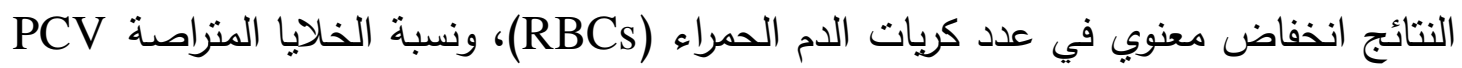

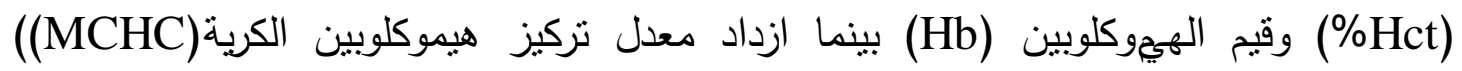

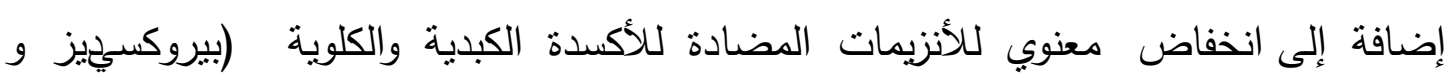

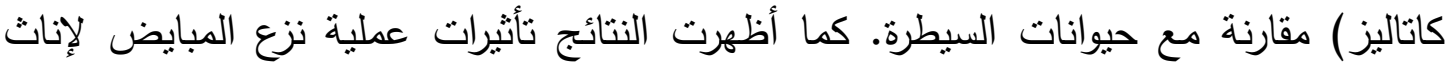

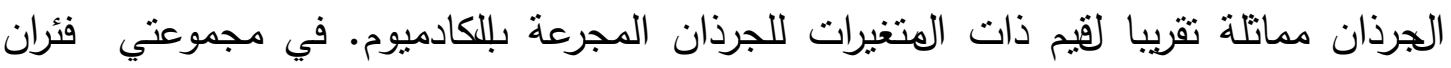

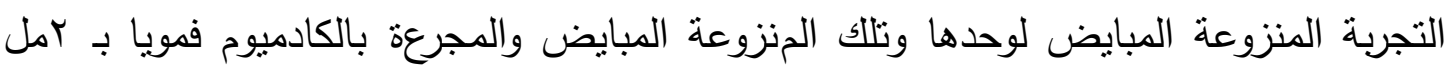

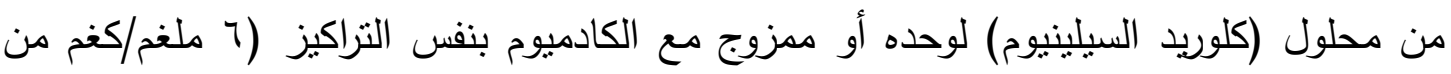

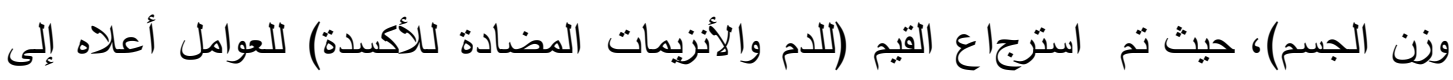
معدلاتها الطبيعية تقريبا باستثناء قيم أنزيم البروكسيدييز التي استجابت بشكل مختلف للمعاملتين 


$$
\begin{aligned}
& \text { أوضحت الدراسة الحالية وجود فعالية وقائية معنوية للسيلينيهم ضد الأضرار الأضرار } \\
& \text { السمية المحفزة عن طريق عملية نزع المبايض و المجرعة بللكادميوم وخاصة عند إعطاء } \\
& \text { السلينيوم مباشرة لكلا المعاملتين. }
\end{aligned}
$$

\begin{abstract}
The present investigation was aimed the possibility protective effect of Selenium chloride against oxidative stress during Ovariectomy and Ovariectomy - cadmium chloride exposure, (25) female rats Albino Wister type weighting $(250-300 \mathrm{~g})$. Rats were randomly divided to five experimental groups, including (5) animals each group. The first group gives normal chow diet (negative control). The second group gives normal chow diet with ovariectomized rat (positive control /Ovx). And three experimentally groups. Ovariectomized (Ovx) sexually mature adult female rats were exposed to sub chronic treatment of cadmium chloride $(\mathrm{CdCl})$ at a dose of $6 \mathrm{mg} / \mathrm{kg} \mathrm{B} . \mathrm{W} / \mathrm{rat}$ then, were orally gavaged daily with $2 \mathrm{ml}$ of the treatment for a period of 28 days, the results show that there was significant reduction in Erythrocytes count (RBCs), Hematocrit percentage P.C.V. (Hct\%) and Hemoglobin value (Hb), While mean corpuscles hemoglobin concentration (MCHC) was increased. Moreover, hepatic and renal antioxidant enzymes activities, peroxidase and Catalase (CAT) were decreased significantly in comparison with the control. The consequences of ovariectomy operation of female rats exhibited the same values for all of the above mentioned Ovx-Cd treatment parameters. Both the experimental rat groups (Ovx and Ovx$\mathrm{Cd})$ were gavaged orally with a $2 \mathrm{ml}$ solution of the dietary supplementation (selenium chloride $\mathrm{SeCl}$ ) individually or in combination with $\mathrm{CdCl}$ at a dose of $6 \mathrm{mg} / \mathrm{kg}$.B.W, resulting recovery effects for blood parameters and antioxidant enzymatic activities were almost restored to control level, except for peroxidase activity that was respond differently in both type of treatment. The present study revealed significant protective action of selenium on the toxicity induced by Ovx or Ovx-Cd in female rats, especially when selenium was subsequently supplemented to both treatments
\end{abstract}

Keywords: Ovariectomy; Cadmium, Selenium, Blood parameters, Peroxidase, CAT

\title{
INTRODUCTION
}

Cadmium is one of the most toxic substances in the environment with wide range of organ toxicity. Along elimination half-life, accumulates in blood, stored primarily in the kidney and liver and excreted through glomuerular filtration in the kidney and may have toxic 
effect on several organs e.g. hematopoietic system, the liver and kidney[1]. It has been proposed that heavy metals acknowledge shortened life span of erythrocytes and inhibit of hemoglobin synthesis[2].

Cadmium has been shown to stimulate the production of intracellular reactive oxygen species (ROS), with membrane protein damage and biomolecules may lead to cellular damage and lipid peroxidation when the rate of ROS generation surpasses the rate of its decomposition by antioxidant defense system, such as the enzymes peroxidase and catalase enzymes [3-4]. Several studies have investigated the effect of ovariectomy or Cadmium-Ovx on antioxidant system and lipid peroxidation[5-7]. The intervention of cellular antioxidant system is believed to protect the cell to some extent from damages arising from Cd-induced ROS production[8-9].

Cadmium treatment alone or in combination with ovariectomy leads to an important elevation of lipid peroxidation (PLO) and decline of antioxidant enzymatic activities such as catalase[10]. The mechanism by which female rats are protected against heavy metal toxicity may be related to the antioxidant properties of native estrogens[11]. In the literature, protective effects of estrogen are widely described in both animals and human, studies demonstrated that in ovariectomy when estrogen was removed, antioxidant enzymes activity was decreased and the free radicals generation was elevated [12-14].

Few studies investigating the combined effects of cadmium and selenium on antioxidant system and lipid peroxidation are available. Thus, we report here the evaluating and prolonged pairing effect of $\mathrm{Cd}$ and $\mathrm{Se}$ administration on ovariectomized rats and determine the protective effects of Selenium against both oxidative stress induced by ovariectomy and Cd-ovariectomy

\section{MATERIALS AND METHODS}

Female rats Albino Wister type weighing (250-300g), were housed in laboratory and maintained at room temperature $\left(25^{\circ} \mathrm{C}\right)$ and allowed water and food add libitum. Rats were randomly divided to five experimental groups, including (5) animals each group. 1- Normal chow diet with negative control vehicle (intact rat). 2- Normal chow diet with ovariectomized rat (positive control). 3-Normal chow diet with ovariectomized -cadmium chloride at a dose of $6 \mathrm{mg} / \mathrm{kgB}$.w. 4- Normal chow diet with equal mixed concentration of cadmium chloride and selenium chloride at a dose of $6 \mathrm{mg} / \mathrm{kg} / \mathrm{bw}$. 5-Normal chow diet with ovariectomized - selenium chloride at a dose of $6 \mathrm{mg} / \mathrm{kgB}$.w. All treatments were gavaged orally with $2 \mathrm{ml}$ solution daily.

Rats in groups 2, 3, 5 were anaesthetized with ether and underwent a bilateral ovariectomy via ventral incision. Ovaries were removed and oviducts replaced with minimum disruption to surrounding soft tissues 
and the incisions were closed with clips. At the end of the experiments, animals were killed by anesthetic over-dose using ether. Blood was drawn via the dorsal vena cava and placed into heparinized tubes in spiramix and analyzed using automatic hematological analyzer (Coulter ACT differential analyzer, Documentation, Bakman Coulter, Inc. Industrial Estate, Germany). The red blood Corpuscles count (RBCs), hemoglobin value $(\mathrm{Hb})$, hematocrit percentage $\mathrm{Hct} \%$ and mean corpuscular hemoglobin concentration (MCHC) were recorded.

Liver and kidney tissue extraction were prepared based on the method described by [15]. Briefly, $100 \mathrm{mg}$ tissue was sliced into pieces and homogenized in ice-cold phosphate buffer $(50 \mathrm{mmol} / \mathrm{l}, \mathrm{pH} .7 .0$, containing $0.1 \mathrm{mmol} / \mathrm{l}$ EDTA to give a $5 \%(\mathrm{w} / \mathrm{v})$ homogenate, then centrifuged at $3000 \mathrm{~g}$ for 10 minutes at $0{ }^{0} \mathrm{C}$. The supernatants used for enzyme assay.

Lipid peroxidation (indicated based on peroxidase activity assay) was performed according to [16]. Briefly, the reaction mixture contained $5 \mathrm{~mL}$ of $50 \mathrm{mM}$ sodium phosphate buffer, pH.7.0, $0.1 \mathrm{~mL}$ of $20 \mathrm{mM}$ guaiacol and $0.02 \mathrm{ml}$ of $40 \mathrm{mM}$ hydrogen peroxide $\left(\mathrm{H}_{2} \mathrm{O}_{2}\right)$. The reaction started by adding $0.2 \mathrm{ml}$ of enzyme extract (prepared as described previously).Enzyme activity determination was performed at $20^{\circ} \mathrm{C}$ by measuring the rate of color development at $470 \mathrm{~nm}$ using Shiamdzu-SP1 650-double beam spectrophotometer. The coefficient (470) of tetraguaicol is $26.6 \mathrm{~cm}-1 \mathrm{mM}-1$.

Catalase (CAT) activity was determined according to the method described by [17] 1984 with slight modification. The enzymatic decomposition of $\mathrm{H} 2 \mathrm{O} 2$ is followed directly by the decrease in absorbance at $240 \mathrm{~nm}$. The differences in absorbance per unit time were used as measure of CAT activity. The enzyme activity is given in $\mathrm{U} / \mathrm{mg} /$ protein

\section{RESULTS}

The blood parameters, Erythrocyte count (RBCs), Hemoglobin value $(\mathrm{Hb})$, Hematocrit $(\mathrm{Hct} \%)$ and Mean corpuscles hemoglobin concentration (MCHC) are presented in TABLE 1. Regardless of ovariectomy RBCs, $\mathrm{Hgb}$ and $\mathrm{Hct} \%$ were decreased, while MCHC) was increased by Cadmium-ovariectomized exposure in comparison to control. The blood parameters were also changed due to ovariectomy from those of intact females. The above decrease in blood parameters values was grater in Cadmium-ovariectomized rats as compared with Ovariectomized females, as well as with those animals experimentally supplemented with both $\mathrm{Se} / \mathrm{Cd}$ combination or $\mathrm{Se}$ alone. The $\mathrm{MCHC}$ was significantly increased in Cadmium-ovariectomized rats while the change was not significant in both Ovariectomized and selenium supplemented group rats either in $\mathrm{Cd}$-combination or alone as compared to intact control rat group. 
TABLE 1: Hematological analyses of rat blood after different treatments, Intact (-Ve control), ovariectomized, (+Ve control/Ovx), cadmium-ovariectomized $\mathrm{Cd} / \mathrm{Ovx}$, cadmium/selenium combination-Ovariectomized $\mathrm{Cd}+\mathrm{Se} / \mathrm{Ovx}$, ovariectomy-selenium Se/ Ovx

\begin{tabular}{|c|c|c|c|c|}
\hline Group & ${\text { RBCS } x 10^{6} / \mathrm{mm}^{3}}$ & Hb g /dl & Hct \% & MCHC (g / dl) \\
\hline -Ve control (intact) & $7.84 \pm 0.379$ & $16.2 \pm 0.44$ & $46.1 \pm 1.89$ & $34.68 \pm 2.11$ \\
\hline+ Ve control (Ovx) & $7.31 \pm 0.399$ & $13.98 \pm 1.875$ & $41.68 \pm 2.352$ & $35.54 \pm 0.364$ \\
\hline Cd / Ovx & $6.564^{*} \pm 0.301$ & $12.88^{*} \pm 0.443$ & $39.24^{*} \pm 1.537$ & $38.834^{*} \pm 0.707$ \\
\hline Cd+Se / Ovx & $6.972 \pm 0.628$ & $13.9 \pm 0.295$ & $39.88 \pm 0.567$ & $35.02 \pm 0.356$ \\
\hline Se/ Ovx & $7.06^{* *} \pm 0.223$ & $14.22^{* *} \pm 1.132$ & $40.52 \pm 2.935$ & $34.86^{* *} \pm 0.270$ \\
\hline
\end{tabular}

The data represent mean SD. Asterisks $(* P<0.05)$ indicate significant difference from control. Asterisks $(* * \mathbf{P}<0.05)$ indicate significant difference from $\mathrm{Ovx} / \mathrm{Cd}$

TABLE (2) shows the antioxidant enzymes status indicated by peroxidase and catalase activities in liver and kidney after sub chronic treatments on Ovariectomized, Ovariectomized-Cd, Ovariectomized/Cd-Se combination and Ovariectomized/Se. Peroxidase was significantly decreased $(\mathrm{P}<0.05)$ in both ovariectomized and ovariectomized-Cd exposed rats as compared to the control, although the ovariectomized rats exposed to $\mathrm{Cd}$ had a deleterious effect, since peroxidase enzyme activity was dropped sharply as compared to that in ovariectomy. Catalase (CAT) activity was significantly decreased $(\mathrm{P}<0.05)$ in both ovariectomized and Ovx-Cd treated rat groups as compared to control animals. The degree of enzymes activity decrease was sever in Ovx-Cd groups in comparison with ovariectomized group. The selenium dietary supplementation alone or simultaneously given in combination with $\mathrm{Cd}$ to $\mathrm{Ovx}$ and-Ovx cadmium rat groups, increase the enzyme activities significantly. Regarding peroxidase activity was different, since there were not restored to the control level.

TABLE 2: Effect of cadmium, cadmium-selenium combination, ovariectomy, ovariectomy -selenium on peroxidase and catalase activity in liver and kidney of rat

\begin{tabular}{|c|c|c|c|c|}
\hline \multirow{3}{*}{ Groups } & \multicolumn{4}{|c|}{ Treatment } \\
\hline & \multicolumn{2}{|c|}{ Peroxidase (U/mg/protein) } & \multicolumn{2}{|l|}{ CAT } \\
\hline & Liver & Kidney & Liver & Kidney \\
\hline -Ve control (intact) & $10.6 \times 10^{-3} \pm 0.12 \times 10^{-3}$ & $13.7 \times 10^{-3} \pm 0.4 \times 10^{-3}$ & $24.24 \pm 1.5$ & $22.38 \pm 2.4$ \\
\hline$+\mathrm{Ve}$ control $(\mathrm{Ovx})$ & $4.8 * \times 10^{-3} \pm 0.12 \times 10^{-3}$ & $7.9 * \times 10^{-3} \pm 0.3 \times 10^{-3}$ & $16.17 * \pm 1.3$ & $17.4^{*} \pm 1.4$ \\
\hline $\mathrm{Cd} / \mathrm{Ovx}$ & $1.4^{* *} \times 10^{-3} \pm 3.6 \times 10^{-3}$ & $1.3 * * \times 10^{-3} \pm 0.17 \times 10^{-3}$ & $7.614 * * \pm 0.2$ & $5.75 * * \pm 0.25$ \\
\hline $\mathrm{Cd}+\mathrm{Se} / \mathrm{Ovx}$ & $3.8^{* * *} \times 10^{-3} \pm 0.14 \times 10^{-3}$ & $6.3^{* * *} \times 10^{-3} \pm 0.32 \times 10^{-3}$ & $18.43 * * * \pm 0.39$ & $17.9 * * * \pm 2.2$ \\
\hline $\mathrm{Se} / \mathrm{Ovx}$ & $4.1^{* * * *} \times 10^{-3} \pm 0.2 \times 10^{-3}$ & $7.3 * * * \times 10^{-3} \pm 0.25 \times 10^{-3}$ & $20.543^{* * *} \pm 1.4$ & $19.79 * * * \pm 1.2$ \\
\hline
\end{tabular}

The data represent mean \pm SD. Asterisks $(* P<0.05)$ indicate significant difference from $-V$ control. Asterisks $(* * \mathbf{P}<\mathbf{0 . 0 5})$ indicate significant difference from Ovx. Asterisks $(* * * \mathbf{P}<\mathbf{0 . 0 5})$ indicate significant difference from Ovx / Cd 
rats exposed to $\mathrm{Cd}$ had a deleterious effect, since peroxidase enzyme activity was dropped sharply as compared to that in ovariectomy. Catalase (CAT) activity was significantly decreased $(\mathrm{P}<0.05)$ in both ovariectomized and Ovx-Cd treated rat groups as compared to control animals. The degree of enzymes activity decrease was sever in Ovx-Cd groups in comparison with ovariectomized group. The selenium dietary supplementation alone or simultaneously given in combination with $\mathrm{Cd}$ to Ovx and-Ovx cadmium rat groups, increase the enzyme activities significantly. Regarding peroxidase activity was different, since there were not restored to the control level.

\section{DISCUSSION}

The effects of ovariectomy and cadmium-Ovx exposure on blood parameters were differ from the intact control rats TABLE 1 . The RBC count, $\mathrm{Hgb}$ value and Hct \% in the experimental animals, either in Ovx or Ovx -Cd treated rats were found to be lower than in intact rat controls. Whereas there was an increase in MCHC value in cadmiumovariectomized rats, which may be due to the production of inadequate maturation of $\mathrm{RBC}$ at rate exceeding the rate of normal $\mathrm{RBC}$ production, as described for other metal effect on hematopoiesis process[18].

The decrease in erythrocyte count, hemoglobin values and hematocrit percentage indicated that anemia was less severe in Ovariectomized-selenium treated females in comparison to Ovx-Cd treated group. It is known that heavy metals impair the heme synthesis and is probably related to the inhibition of the hemoglobin synthesis and to various alteration of erythrocyte membrane properties, leading to an increased fragility, deformability, RBC destruction and eventually a shortened life span[2,19,20]. A part from directed inducing, the generation of reactive oxygen species (ROS) such as hydrogen peroxide $(\mathrm{H} 2 \mathrm{O} 2)$, an element can indirectly induce oxidative stress by increase the vulnerability of membrane to the attack of ROS. The effect of heavy metal on red blood corpuscles membrane in particular have been intensely analyzed because $\mathrm{RBCs}$ are more vulnerable to oxidative damage than many other cells[21]. One mechanism by which metals produce injury is assumed to be through generation of free radicals and lipid peroxidation. Free radicals in the living body are highly reactive and can cause several disorders[21,22] found that hemolysis induced by hemolytic agents such as heavy metals was associated with a high degree of peroxidation.

Peroxidase is one of the major components of the antioxidant system[23]. In the present study, (TABLE 2) showed an increase in lipid peroxidation, due to a sharp decrease in peroxidase and catalase antioxidant enzymatic activities, following both ovariectomy operation 
and Cd-Ovx treatment, as compared to control. This demonstrated that Ovx and Cd-Ovx treated rats impair the enzymatic antioxidant defense system in liver and kidney tissues. [15,23]

The decline in peroxidase and CAT activities in Ovx and Cd- Ovx treated rats may be due to inhibition of its ability in the scavenging of free radicals. As it has been reported that Ovariectomy could trigger lipid peroxidation, which in turn reduce the enzymatic antioxidant activities. As a consequence the production of ROS enhanced due to the removal of estrogen produced normally by ovaries[15,24].

Both enzymatic activities that had restoring effect to the control level in studied parameters after antidotes supplementation may be due to its protection effect against metal-induced oxidative stress. Recent investigations mentioned that antidotes of Selenium could enhances cadmium transport and decrease its uptake in rat intestine and produce protection against cadmium-induced anemia[25-27]. The study ofApostolski et $\underline{\text { al }}$. demonstrated that exogenous administration of selenium have some stimulatory effect on ovarian peroxidase activity[28].

In the literature, protective effect of estrogen is widely described in both humans and animals[29]. Estrogens may be able to inhibit the generation of free radicals and decrease peroxide levels resulting free radical suppression in rat liver[12,30,31]. Thus the possibility exist that antioxidant such as selenium in the present study, could decrease or prevent some pathological consequences of heavy metal toxicities. Results on other metals effects hypothesized that endogenous estrogen have antioxidant capability[14]. This could explain the differences between intact and ovariectomy in the expression of cadmium exposure effects.

We can concluded that ovariectomy and cadmium/ ovariectomy can increase the production of ROS that results in RBC membrane destruction and function beside the impairment of antioxidant enzymes activities. The antidotes selenium supplementation could replace the act of ovarian estrogen in its protective action.

\section{REFERENCES}

1) Skerfving, S.; Gerhardson, L., and Schutz, I.: J.Trace Elem. Exp. Med., 11, 289-301 (1998).

2) Toplan, S.; Ozcelik, D. and Gulyasar, T.: Trac. Med. Biolo., 18, 179-182 (2004).

3) Dally, H. and A. Hartwig: Carcinogenesid, 18, 1021-1026 (1997).

4) Stohs, S. T.; Bagchi, D. and Hassoun, E.: J.Environ.Pathol. Toxicol. Oncol., 20(2), 77-88 (2002).

5) Stajn, A.; Zikic, R. V. and Ognjanovic B.: Comp. Biochem. Physilo., 117,167-172 (1997). 
6) Yalin, S.; Comelekekoglu, U. and Bagis, S.: Ecotoxicology and Environmental Safety, 65, 140-144 (2006).

7) Comelekoglu, U.; Yalin, S. and Bagis, S.: Ecotoxicology and Environmental Safety, 66, 267 -271, (2007).

8) Ozgonul, M.; Oge, A. and Sezer, E. D.: Endocri. Res., 29, 183-189 (2003).

9) Ikediob, C. O.; Badisa, V. and Takem, L. A.: Int. J. Moll. Med., 14, 87-92 (2004).

10) Paynter, D. I.; Moir, R. J. and Underwood, E. J.: J.Nutr., 109, 1570-1576 (1979).

11) Rymaszewski, Z.: J.Clin.Endocrinol.Metab, 77, 1095-1097 (1993).

12) Ayres, S.; Abplanalp, W.; Liu, J. H. and Subbiah, M. T.: Am. J. Physiol., 274, 1002-1008 (1998).

13) Barp, J.; Aranjo, A. S. R. and Rigatto, K. V.: Brazillian Journalof Medical and Biological Research, 35, 1075-1081 (2002).

14) Isabelle, E. G.; Andrzej, M. and Edmond R.: Journal of the American College of Nutrition, 22, 239-246 (2003).

15) Gerardo, B.; Zhong, J. and Jyotirmoy, N.: Clinical and Experimental Pharmacology and Physiology, 34, 70-76 (2007).

16) Chance, B. S.; Park, K. H. and Lund, D.B.: J.Food Science, 53, 920-923 (1988).

17) Aebi, H.: Methods Enzymol., 105, 121-126 (1984).

18) Osterode, W.; Barnas, U. and Geisster, K.: Occup. Environ. Med., 56, 106-109 (1999).

19) Zimmermann, L.; Payes, N.; Anteb, H. and Hatfi, A.: Trace Elem. Res., 38, 311-318 (1991).

20) Donaldson, W. E. and Knowlea, S. O.: Comp.Biochem. Physiol., 104, 377-379 (1993).

21) DeSliva, P.: Br. J. Ind. Med., 38, 209-217 (1981).

22) Nomiyama, K. and Nomiyama, H.: J. Trace Elem. Exp. Med., 11, 27-88 (1998).

23) Rabarov, S. R. and Benov, L. C.: Biochim. Biophys. Acta, 640, 721-726 (1981).

24) Susa, S.; Ueno, S. and Furukawa, Y.: Arch.Toxicol., 71, 20-24 (1996).

25) Sahajian, B. M.; Harding, B. and Perry I.: J. Nutr., 93, 291-297 (1967).

26) Fox, M.R.S. and Fry B.E.: Science, 169, 989-991 (1970).

27) Helzlsouer, K. J.; Alberg, A.J. and Norkus E. P.: J. Natl. Cancer Inst., 88, 32-37 (1996).

28) Apostolski, S.; Marinkovic, Z. and Nikolic, A.: J. Environ. Pathol. Toxicol. Oncol., 17, 325-329, (1998).

29) Mendelsohn, M. E. and Karas, R. H.: N. Engl. J. Med., 340, 18011811, (1999).

30) Huh, K.; Shin, U. S.; Choi, J. W. and Lee, S. I.: Arch. Pharm. Res., 17, 109-114 (1994).

31) Yagi, K.: Acta Biochim. Pol., 44, $701-709$ (1997). 